\title{
Real-world treatment patterns and adverse events in metastatic renal cell carcinoma from a large US claims database
}

Sumanta Pal ${ }^{*}$, Jun Gong ${ }^{2}$, Shivani K. Mhatre ${ }^{3}$, Shih-Wen Lin ${ }^{3}$, Andy Surinach ${ }^{4}$, Sarika Ogale ${ }^{5}$, Rini Vohra ${ }^{6}$, Herschel Wallen ${ }^{7}$ and Daniel George ${ }^{8}$

\begin{abstract}
Background: Vascular endothelial growth factor (VEGF), tyrosine kinase (TK) and mechanistic target of rapamycin kinase (mTOR) inhibitors are common first-line $(1 \mathrm{~L})$ treatments for metastatic renal cell carcinoma (mRCC). Despite treatment availability, the 5 -year survival rate in patients diagnosed at the metastatic stage is only $\approx 10 \%$. To gain contemporary insights into RCC treatment trends that may inform clinical, scientific and payer considerations, treatment patterns and adverse events (AEs) associated with $1 \mathrm{~L}$ therapy were examined in a retrospective, longitudinal, population-based, observational study of patients with mRCC.

Methods: US administrative claims data (Truven Health MarketScan Commercial Databases) were used to assess trends in $1 \mathrm{~L}$ treatment initiation in mRCC (2006-2015) and characterize patterns of individual $1 \mathrm{~L}$ treatments, baseline characteristics, comorbidities and treatment-related AEs from 2011 through 2015. Outcomes were evaluated by drug class and route of administration.
\end{abstract}

Results: Ten-year trend analysis $(n=4270)$ showed that TKNEGF-directed therapy rapidly became more common than mTOR-directed therapy, and oral treatments were favored over intravenous (IV) treatments. Overall, 1992 eligible patients initiated $1 \mathrm{~L}$ treatment for mRCC from 2011 through 2015: 1752 (88\%) received TKVEGF-directed agents and 233 (12\%) received mTOR-directed agents; 1674 (84\%) received oral treatments, and $318(16 \%)$ received IV treatments. The most common $1 \mathrm{~L}$ treatment was sunitinib $(n=849)$, followed by pazopanib $(n=631)$, temsirolimus $(n=157)$ and bevacizumab $(n=154)$. Patient characteristics and comorbidities, including age, diabetes and congestive heart failure, were independent predictors of $1 \mathrm{~L} \mathrm{mRCC}$ treatment choice. The three most common potentially $1 \mathrm{~L}$ treatment-related AEs were nausea/vomiting (128.2 per 100 patient-years [PY]), hypertension (69 per $100 \mathrm{PY}$ ) and renal insufficiency (44.6 per $100 \mathrm{PY}$ ). A wide variety of agents were used as second-line (2 L) therapy. Substantial latency of onset was observed for several potentially treatment-related toxicities in patients treated with TKNEGF- or mTOR-directed agents.

Conclusions: In the US, 1 L TKNEGF inhibitor uptake in recent years appears largely in line with national approvals and guidelines, with varied $2 \mathrm{~L}$ agent use. Although retrospective evaluation of claims data cannot assess underlying causality, insights from these real-world RCC treatment and AE patterns will be useful in informing medical and payer decisions.

Keywords: Treatment patterns, Adverse events, Renal cell carcinoma, Targeted therapy, Administrative claims

\footnotetext{
* Correspondence: spal@coh.org

'Department of Medical Oncology and Experimental Therapeutics, City of Hope National Medical Center, 1500 East Duarte Road, Duarte, CA 91010, USA

Full list of author information is available at the end of the article
}

(c) The Author(s). 2019 Open Access This article is distributed under the terms of the Creative Commons Attribution 4.0 International License (http://creativecommons.org/licenses/by/4.0/), which permits unrestricted use, distribution, and reproduction in any medium, provided you give appropriate credit to the original author(s) and the source, provide a link to the Creative Commons license, and indicate if changes were made. The Creative Commons Public Domain Dedication waiver (http://creativecommons.org/publicdomain/zero/1.0/) applies to the data made available in this article, unless otherwise stated. 


\section{Background}

Kidney cancer is the eighth most common cancer in the United States [1]. Renal cell carcinoma (RCC) is the most common type of adult kidney cancer, making up about $90 \%$ of diagnoses [2]. Approximately $65 \%$ of patients with newly diagnosed RCC have localized disease at the time of diagnosis, while 25 to $30 \%$ have advanced or metastatic disease [1, 3]; approximately 20 to $40 \%$ of patients with localized RCC will progress to metastatic RCC (mRCC) [4]. The prognosis associated with mRCC is poor, with a 5-year relative survival rate of approximately 8 to $12 \%$ in patients initially diagnosed with distant metastatic disease [1, 5]. Progression-free survival (PFS) has been shown to predict overall survival (OS) in patients with $\mathrm{mRCC}[6]$; therefore, first-line $(1 \mathrm{~L})$ treatment for mRCC is crucial to improving outcomes.

In the last decade, several tyrosine kinase (TK) inhibitors, vascular endothelial growth factor (VEGF) inhibitors (collectively, TK/VEGF inhibitors) and mechanistic target of rapamycin (mTOR) inhibitors have been approved in the United States for $1 \mathrm{~L}$ use in patients with mRCC. These agents have notably improved efficacy [4] compared with interferon (IFN)- $\alpha$ and interleukin 2 (IL-2), the previous standards of care $[7,8]$. Sunitinib and pazopanib, both multitargeted TK inhibitors that also target VEGF, have been shown to improve objective response rate (ORR) and PFS compared with either IFN- $\alpha$ or placebo, respectively $[9,10]$, and pazopanib was also found to be non-inferior to sunitinib with respect to PFS, with similar OS observed [11]. For $1 \mathrm{~L}$ treatment of clear cell RCC, current National Comprehensive Cancer Network $(\mathrm{NCCN})$ guidelines recommend several treatment options with distinct mechanisms of action, including sunitinib or pazopanib as category 1 options [8]. Since the introduction of these agents, however, data on their use in routine clinical practice have been limited [12-14] and have tended to focus on specific patient subgroups or selective treatments. With the changing landscape in the $1 \mathrm{~L}$ treatment of mRCC, an understanding of real-world treatment use, sequencing and associated adverse events (AEs) of historic but widely used and recommended current standard of care treatments is required $[15,16]$ and can provide practitioner, researcher and payer insights into the care and benefit:risk profiles of mRCC treatment.

\section{Methods}

\section{Study objectives}

The aims of this retrospective, longitudinal, populationbased, observational analysis were to (1) assess 10-year trends in $1 \mathrm{~L} \mathrm{mRCC}$ treatment initiation by drug class and route of administration (from 2006 through 2015) and (2) characterize the patterns of individual $1 \mathrm{~L}$ treatments and baseline characteristics and comorbidities of treated patients (from 2011 through 2015). Additionally, in exploratory analyses, clinical factors and potentially treatment-related AEs associated with $1 \mathrm{~L}$ treatments during the latter period were assessed by drug class and route of administration.

\section{Study design and databases}

US administrative claims data from the Truven Health MarketScan Commercial Claims and Encounters (Commercial) and Medicare Supplemental and Coordination of Benefits (Medicare) Databases were used in this study. Cross-sectional data were used for the trend analysis, and longitudinal data were used for all other study objectives (Fig. 1). The MarketScan Research Databases make up the largest private-sector healthcare database in the United States and include information from employer-sponsored plans that provide health benefits to over 15 million people annually, including employees, their spouses and dependents, approximately $10 \%$ of whom are aged $\geq 65$ years. All data on treatment utilization and medical conditions were derived from records of prescription claims for treatment and medical claims for conditions, respectively. This study used Truven MarketScan retrospective administrative claims data. Data were de-identified and comply with the Health Insurance Portability and Accountability Act and the 1964 Helsinki Declaration and its later amendments or comparable ethical standards. Thus, Institutional Review Board approval was not required, and formal informed consent was not obtained.

\section{Patient populations and treatment definitions}

For the 10-year trend analysis, patients aged $\geq 18$ years with $\mathrm{mRCC}$ who initiated $1 \mathrm{~L}$ treatment between January 1, 2006, and December 31, 2015, were included (Fig. 1a). For analyses of treatment patterns, patient characteristics and AEs, patients aged $\geq 18$ years with $\mathrm{mRCC}$ who initiated $1 \mathrm{~L}$ treatment between January 1, 2011, and December 31, 2015 (total study period July 1, 2010 to September 30, 2016), were included (Fig. 1b). The index date was defined as the date of $1 \mathrm{~L}$ treatment initiation for $\mathrm{mRCC}$, and patients were followed for a minimum of 6 months until the end of continuous enrollment. Eligibility criteria are shown in Table 1. Based on similar mechanisms of action, agents were grouped as TK (sunitinib, sorafenib, pazopanib and axitinib)/VEGF inhibitors (bevacizumab \pm IFN- $\alpha$ ) or mTOR-directed therapy (temsirolimus and everolimus). These agents were classified by route of administration as oral (sunitinib, sorafenib, pazopanib, axitinib and everolimus) or intravenous (IV; bevacizumab \pm IFN- $\alpha$, temsirolimus and IL-2).

\section{Measures}

Treatment duration was defined as the number of days from the index date to either (1) the end of the treatment 


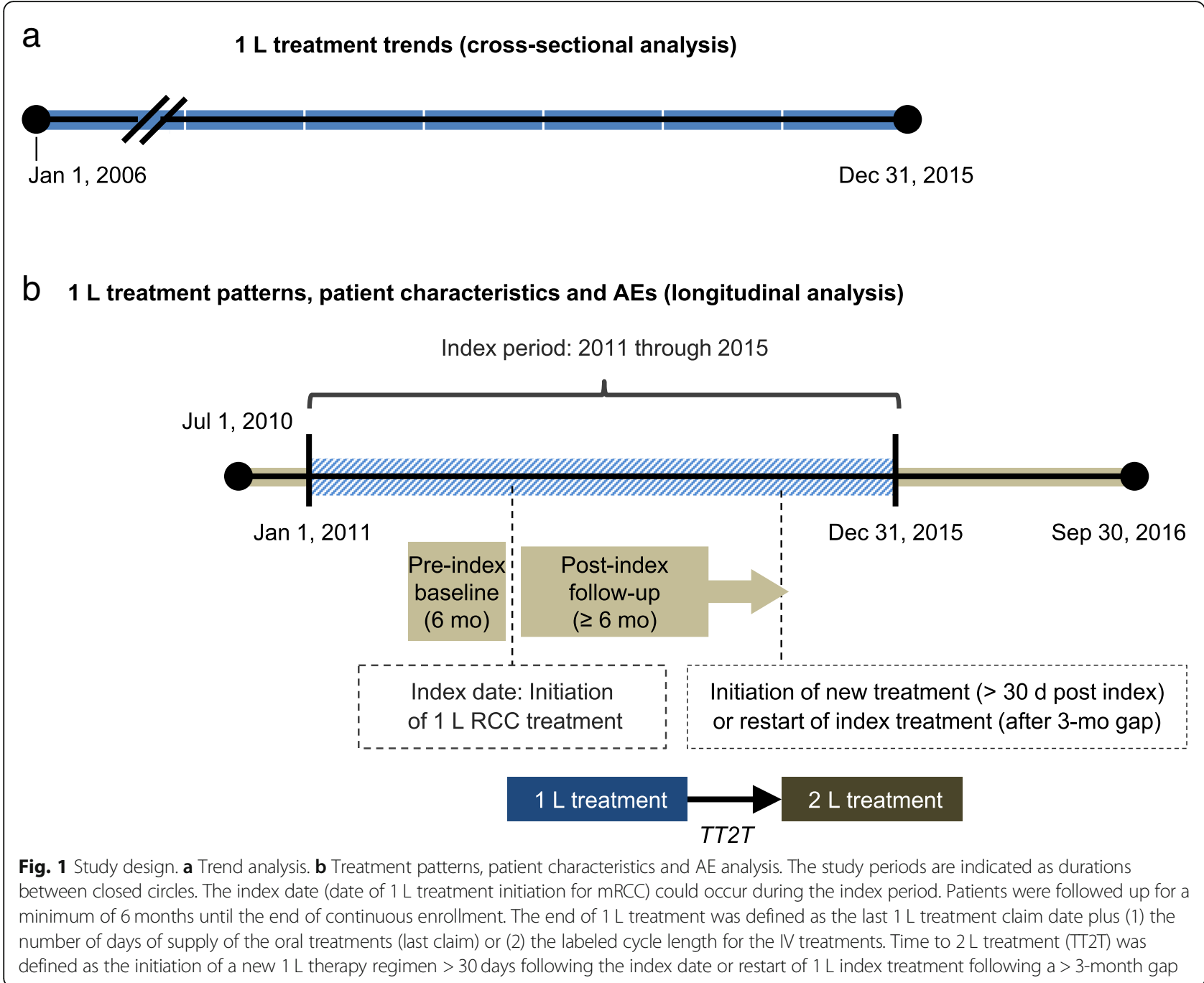

Table 1 Eligibility criteria (longitudinal analysis)

Inclusion criteria

$\geq 2$ claims with ICD-9 code 189.0 or ICD-10 code C64.xx for malignant neoplasm of the kidney on separate dates ( $\geq 30$ days apart) during the index date period

First claim (ever) for a first-line mRCC agent (sunitinib, pazopanib, bevacizumab \pm IFN- $a^{a}$, temsirolimus, everolimus, sorafenib, axitinib, interleukin 2) occurs during the index date period, within 30 days before the first mRCC claim and up to the end of the rolling index period (patients with two different agents within 5 days of each other were excluded)

Aged $\geq 18$ years at index date

Continuous enrollment eligibility 6 months pre-index and 6 months post-index dates with no gap

Total no. of patients after applying all the inclusion criteria

Exclusion criteria

Evidence of TCC ( $\geq 1$ claim) from 30 days pre-index date through the entire follow-up period. TCC was identified by receipt of agent indicated for TCC

$\geq 2$ claims for 1 primary cancer from 6 months pre-index date through the index date (except for sites to which primary RCC commonly metastasizes, such as lung, bone, brain and liver)

${ }^{a}$ For the combination treatment with bevacizumab + IFN- $a$, the index date is the first occurring claim of either agent. The other drug claim must have occurred within a period of 30 days after the first agent claim to qualify as combination treatment. TCC transitional cell (urothelial) carcinoma 
regimen (with a $\leq 3$-month gap permitted) or (2) a switch to a new treatment after 30 days following the index date. End of $1 \mathrm{~L}$ treatment was calculated as the last $1 \mathrm{~L}$ treatment claim date plus (1) the number of days' supply of oral treatments (last claim) or (2) the labeled cycle length for the IV treatments. In the event of a change to a new treatment within 30 days of the initial index date, followed by a subsequent refill of the second drug, the second drug was considered the $1 \mathrm{~L}$ index drug and initiation of the second drug was then defined as the $1 \mathrm{~L}$ index date. Time to $2 \mathrm{~L}$ treatment (TT2T) was defined as the initiation of a new treatment more than 30 days following the index date or restart of $1 \mathrm{~L}$ index treatment following a > 3-month gap. Baseline comorbidities were identified and incorporated into the modified DeyoCharlson Comorbidity Index (DCCI) score (including non-cancer comorbidities), whereby a higher score reflects a high comorbidity burden $[17,18]$. Secondary metastases were identified using ICD-9/ICD-10-CM codes and categorized as lung (197.0-197.3, C78.0-C78.3), liver (197.7, C78.7), brain (198.3, 198.4, C79.3, C79.49), bone (198.5, C79.5) and other sites.

Potentially treatment-related AEs were identified using corresponding International Classification of Diseases (ICD), Ninth Revision and ICD, Tenth Revision, Clinical Modification codes in the administrative claims data that occurred during the treatment duration up to 30 days after the last $1 \mathrm{~L}$ drug claim. Such codes are likely associated with medical attention, though administrative claims databases are unable to provide definitive causality. The AEs evaluated in this study were chosen from searching the product labels for each of the drugs described, and only those that were reported to be grade 3 or 4 severity and occurring with a $>5 \%$ incidence were included [19-25]. Additional AEs, such as diarrhea, fatigue/asthenia and hand-foot syndrome, which are commonly associated with checkpoint inhibitors, were also included in order to provide historical estimates for the targeted therapies (Additional file 1: Table S1).

\section{Statistical analysis}

All analyses were assessed as a function of the $1 \mathrm{~L}$ index treatment, including drug class and route of administration. Categorical variables were reported as counts and percentages, and continuous variables were reported as means with standard deviations or medians with interquartile ranges (Q1-Q3). For the 10-year trend analysis, the proportion of patients receiving the index treatment by drug class and route of administration each year was determined.

Treatment patterns were evaluated as the number and percentage of patients receiving each $1 \mathrm{~L}$ treatment and switching to the corresponding second-line $(2 \mathrm{~L})$ treatment, the duration of $1 \mathrm{~L}$ treatment and TT2T. Kaplan-Meier methods (median, 95\% CI) were used for the duration of $1 \mathrm{~L}$ treatment and TT2T. The duration of $1 \mathrm{~L}$ treatment was evaluated to measure the difference in time from the index date to the end of $1 \mathrm{~L}$ treatment, with an event defined as discontinuation of $1 \mathrm{~L}$ treatment and switch to a $2 \mathrm{~L}$ treatment or discontinuation of $1 \mathrm{~L}$ treatment $>3$ months prior to the enrollment eligibility end date (for patients who did not switch to a $2 \mathrm{~L}$ therapy). Patients who discontinued $1 \mathrm{~L}$ treatment within 3 months of the enrollment eligibility end date were censored at the enrollment eligibility end date. For TT2T evaluation, an event was defined as a switch to a $2 \mathrm{~L}$ treatment. Patients who did not switch were censored at the end of $1 \mathrm{~L}$ treatment or the end of continuous enrollment, whichever was earlier.

Differences in baseline patient characteristics by $1 \mathrm{~L}$ treatment class (TK/VEGF inhibitor vs mTOR inhibitor) and route of administration (oral vs IV) were compared using a univariate $t$ test and $\chi^{2}$ test (or Fisher exact test when appropriate) for continuous and categorical variables, respectively. Variables found to be statistically significant $(P<0.2)$ in the univariate analyses were used in the multivariate logistic regression to model the odds of choosing the drug class or route of administration. Irrespective of the $P$ value in the univariate analysis, age, sex and index year were covariates in the multivariate analysis.

AEs were reported as incidence rate per 100 patient-years (IR per $100 \mathrm{PY}$ ) in the total population and in subpopulations by drug class and route of administration. IR was calculated as the number of patients with at least one AE after the index date, divided by the total PY at risk. If a patient did not have an $\mathrm{AE}$, his/her person-time was counted up to 30 days after the end of $1 \mathrm{~L}$ treatment or the end of eligibility, whichever occurred first. A washout period of 30 days prior to the index date was applied to exclude patients with pre-existing AEs of interest when identifying incidence of non-chronic AEs. For chronic conditions, such as hypertension, hypotension, hepatitis, thyroid disorders, renal insufficiency, adrenal insufficiency and myasthenia gravis, a 365-day washout period was applied to identify true incident events.

\section{Results}

Ten-year trends in $1 \mathrm{~L}$ treatment initiation for $\mathrm{mRCC}$ : cross-sectional analysis

Between 325 and 508 patients were evaluated each year from 2006 through 2015 (Fig. 2). During the 10-year study period, TK/VEGF-directed treatments were much more commonly initiated than were mTOR-directed or IL-2 treatments. Initiation of TK/VEGF-directed agents ranged from 91 to $95.7 \%$ from 2006 through 2009, dropped to $70.5 \%$ in 2009 and ranged from 71.5 to 84.5\% between 2009 and 2015 (Fig. 2a). Starting in 2009 and extending through 2015, a downward trend for 

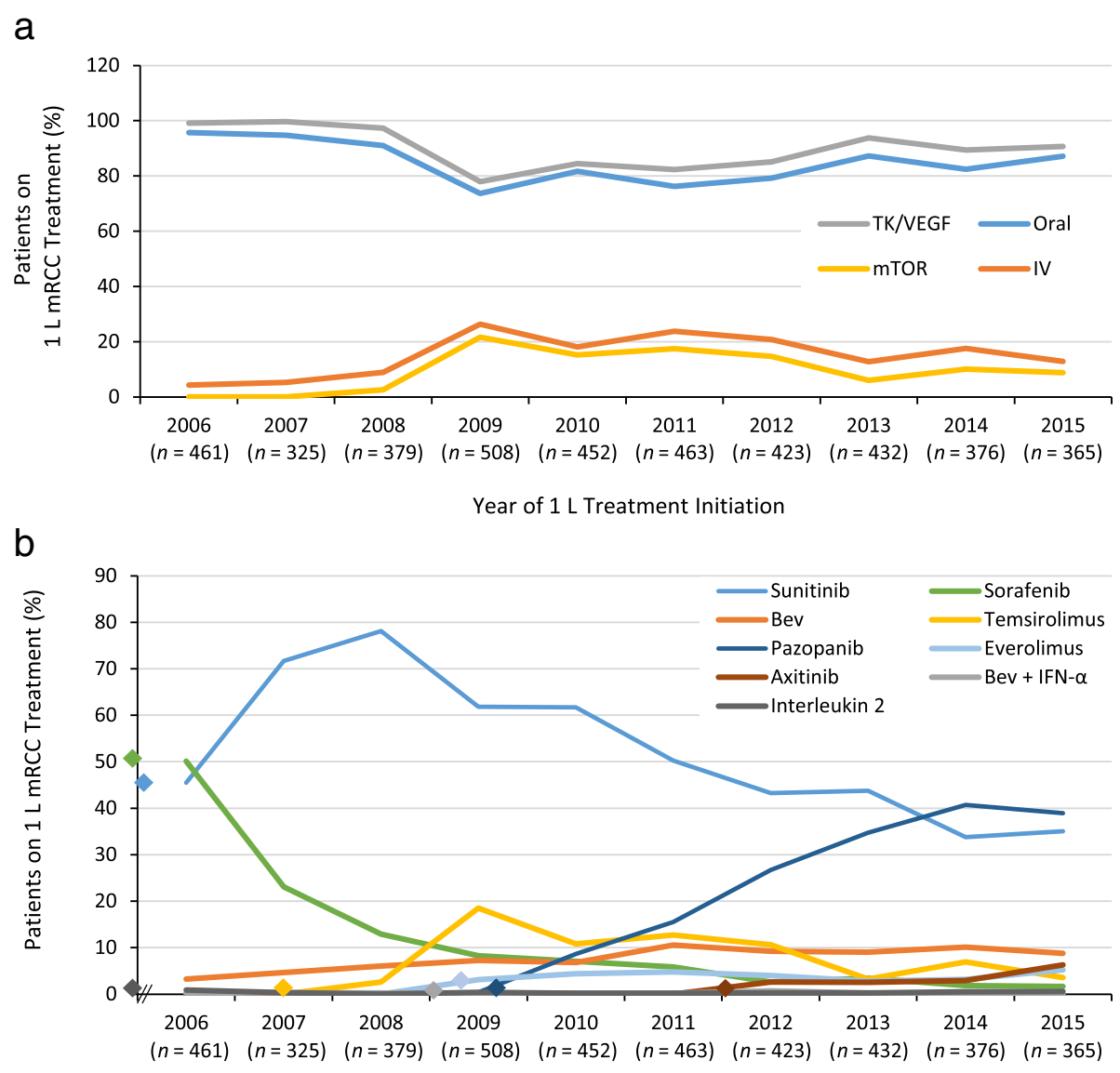

Year of 1 L Treatment Initiation

Fig. 2 Trends in $1 \mathrm{~L}$ treatment for mRCC by drug class and route of administration (2006-2015). a Trends by drug class and route of administration. TKNEGF inhibitors included sunitinib, pazopanib, sorafenib, axitinib and bevacizumab \pm IFN-a. mTOR treatments included temsirolimus and everolimus. Orally administered agents included sunitinib, pazopanib, sorafenib, axitinib and everolimus; IV treatments included bevacizumab \pm IFN-a, temsirolimus and interleukin 2. For the oral (blue line) vs IV (orange line) comparison, the percentage of each group sums to 100\% for each year. For the TKNEGF (grey line) vs mTOR (yellow line) comparison, the percentage of each group may sum to $<100 \%$ because interleukin 2 was not included (accounts for $<1 \%$ of patients in each year). $\mathbf{b}$ Trends by individual treatment. Trends are plotted as a single value for the entire year, and approximate timings for US FDA approvals are indicated by diamond symbols in part b (pre-2006 approvals are shown adjacent to the $y$-axis). Approvals plotted include $1 \mathrm{~L}$ sunitinib (January 26, 2006), $1 \mathrm{~L}$ pazopanib (October 19, 2009), 2 L sorafenib (December 20, 2005), 2 L axitinib (January 27, 2012), 1 L bevacizumab \pm IFN-a (July 31, 2009), $1 \mathrm{~L}$ temsirolimus (May 30, 2007), $2 \mathrm{~L}$ everolimus (March 30, 2009) and $1 \mathrm{~L}$ interleukin 2 (May 5, 1992). In each given year, the percentage of patients receiving each indicated agent sums to $100 \%$

sunitinib (61.8-35.1\%) and an upward trend for pazopanib (0.4-38.9\%) were observed (Fig. 2b). Initiation of VEGF-directed therapy, consisting primarily of bevacizumab monotherapy, ranged from 3.3 to $10.1 \%$ (20062015), without any distinct trend. mTOR inhibitor use, predominantly temsirolimus, increased rapidly from $2.6 \%$ in 2008 to $21.7 \%$ in 2009 followed by a downward trend to $8.8 \%$ in 2015 . During the study period, oral treatments were also much more common that IV treatments, although initiation of oral treatments dropped from 95.7 to $73.6 \%$ and that of IV treatments increased from 4.3 to $26.4 \%$ between 2006 and 2009. After 2009, oral initiation ranged from 76.2 to $87.3 \%$ and IV initiation ranged from 12.7 to $23.8 \%$ (Fig. 2a).
Baseline clinical and demographic characteristics and $1 \mathrm{~L}$ treatment patterns: longitudinal analysis

Overall, 1992 patients initiated $1 \mathrm{~L}$ treatment for mRCC from 2011 through 2015 and were eligible for the longitudinal analysis (Table 1). The cohort had a median (Q1-Q3) follow-up of 15.6 (10.2-25.9) months. The median age was 62 years, and the majority of patients were male $(70 \%)$ and largely from urban areas $(82 \%)$. The mean modified DCCI score was 0.7 , and $63 \%$ of patients had no reported comorbidities. The most common comorbidities (in $>10 \%$ of patients) were diabetes (27\%), chronic kidney disease (20\%), liver disease (18\%) and chronic obstructive pulmonary disease (12.6\%). Characteristics of $1 \mathrm{~L}$ treatment subgroups are shown in Table 2. 
Table 2 Key baseline characteristics of patients initiating 1 L RCC treatment (2011-2015): drug class and administration route

\begin{tabular}{|c|c|c|c|c|c|c|c|c|}
\hline \multirow[t]{2}{*}{ Characteristic } & \multicolumn{2}{|c|}{$\begin{array}{l}\text { TKNEGF inhibitor } \\
(n=1752)\end{array}$} & \multicolumn{2}{|c|}{$\begin{array}{l}\text { mTOR inhibitor } \\
(n=233)\end{array}$} & \multicolumn{2}{|c|}{$\begin{array}{l}\text { Oral } \\
(n=1674)\end{array}$} & \multicolumn{2}{|c|}{$\begin{array}{l}\text { IV } \\
(n=318)\end{array}$} \\
\hline & $\mathrm{n}$ & $\%$ & $n$ & $\%$ & $\mathrm{n}$ & $\%$ & $\mathrm{n}$ & $\%$ \\
\hline Age at diagnosis, median (Q1-Q3), years & \multicolumn{2}{|c|}{$62(56-70)$} & \multicolumn{2}{|c|}{$62(56-71)$} & \multicolumn{2}{|c|}{$61(56-69)$} & \multicolumn{2}{|c|}{$64(57-76)$} \\
\hline Male & 1220 & 69.6 & 166 & 71.2 & 1176 & 70.3 & 215 & 67.6 \\
\hline \multicolumn{9}{|l|}{ Employment status } \\
\hline Active & 568 & 32.4 & 69 & 29.6 & 563 & 33.6 & 79 & 24.8 \\
\hline Retiree & 652 & 37.2 & 78 & 33.5 & 617 & 36.9 & 113 & 35.5 \\
\hline Long-term disability & 11 & 0.6 & 1 & 0.4 & 8 & 0.5 & 4 & 1.3 \\
\hline Other/unknown & 521 & 29.7 & 85 & 36.5 & 486 & 29.0 & 122 & 38.4 \\
\hline \multicolumn{9}{|l|}{ Region } \\
\hline Northeast & 327 & 18.7 & 33 & 14.2 & 303 & 18.1 & 57 & 17.9 \\
\hline North Central & 467 & 26.7 & 52 & 22.3 & 451 & 26.9 & 68 & 21.4 \\
\hline South & 645 & 36.8 & 104 & 44.6 & 622 & 37.2 & 131 & 41.2 \\
\hline West & 296 & 16.9 & 40 & 17.2 & 280 & 16.7 & 59 & 18.6 \\
\hline Unknown & 17 & 1.0 & 4 & 1.7 & 18 & 1.1 & 3 & 0.9 \\
\hline \multicolumn{9}{|l|}{ Metropolitan statistical area } \\
\hline Urban & 1424 & 81.3 & 195 & 83.7 & 1359 & 81.2 & 267 & 84.0 \\
\hline Rural & 328 & 18.7 & 38 & 16.3 & 315 & 18.8 & 51 & 16.0 \\
\hline \multicolumn{9}{|l|}{ Insurance plan type } \\
\hline Comprehensive & 313 & 17.9 & 45 & 19.3 & 288 & 17.2 & 70 & 22.0 \\
\hline $\mathrm{HMO}$ & 204 & 11.6 & 22 & 9.4 & 189 & 11.3 & 38 & 12.0 \\
\hline POS & 130 & 7.4 & 17 & 7.3 & 120 & 7.2 & 28 & 8.8 \\
\hline PPO & 926 & 52.9 & 125 & 53.7 & 896 & 53.5 & 158 & 49.7 \\
\hline Other & 179 & 10.2 & 24 & 10.3 & 181 & 10.8 & 24 & 7.6 \\
\hline \multicolumn{9}{|l|}{ Insurance type } \\
\hline Commercial & 1120 & 63.9 & 142 & 70.0 & 1100 & 65.7 & 169 & 53.1 \\
\hline Medicare & 632 & 36.1 & 91 & 39.1 & 574 & 34.3 & 149 & 46.9 \\
\hline \multicolumn{9}{|l|}{ Index year } \\
\hline 2011 & 350 & 20.0 & 78 & 33.5 & 341 & 20.4 & 88 & 27. 7 \\
\hline 2012 & 350 & 20.0 & 62 & 26.6 & 333 & 19.9 & 80 & 25.2 \\
\hline 2013 & 392 & 22.4 & 25 & 10.7 & 373 & 22.3 & 45 & 14.2 \\
\hline 2014 & 327 & 18.7 & 38 & 16.3 & 309 & 18.5 & 58 & 18.2 \\
\hline 2015 & 333 & 19.0 & 30 & 12.9 & 318 & 19.0 & 47 & 14.8 \\
\hline Mean DCCI score (Q1-Q3) & 0.70 & & 0.76 & & 0.66( & & 0.93 & \\
\hline \multicolumn{9}{|l|}{ Comorbidities } \\
\hline Diabetes & 484 & 27.6 & 48 & 20.6 & 442 & 26.4 & 90 & 28.3 \\
\hline CKD & 346 & 19.8 & 54 & 23.2 & 317 & 18.9 & 84 & 26.4 \\
\hline Liver disease & 307 & 17.5 & 40 & 17.2 & 306 & 18.3 & 45 & 14.2 \\
\hline COPD & 217 & 12.4 & 33 & 14.2 & 212 & 12.7 & 39 & 12.3 \\
\hline $\mathrm{CHF}$ & 113 & 6.5 & 37 & 15.9 & 111 & 6.6 & 40 & 12.6 \\
\hline \multicolumn{9}{|l|}{ Secondary metastatic sites } \\
\hline Lung & 798 & 45.6 & 101 & 43.4 & 804 & 48.0 & 99 & 31.1 \\
\hline Liver & 181 & 10.3 & 39 & 16.7 & 186 & 11.1 & 34 & 10.7 \\
\hline Brain & 161 & 9.2 & 25 & 10.7 & 162 & 9.7 & 26 & 8.2 \\
\hline
\end{tabular}


Table 2 Key baseline characteristics of patients initiating 1 L RCC treatment (2011-2015): drug class and administration route (Continued)

\begin{tabular}{|c|c|c|c|c|c|c|c|c|}
\hline \multirow[t]{2}{*}{ Characteristic } & \multicolumn{2}{|c|}{$\begin{array}{l}\text { TKNEGF inhibitor } \\
(n=1752)\end{array}$} & \multicolumn{2}{|c|}{$\begin{array}{l}\text { mTOR inhibitor } \\
(n=233)\end{array}$} & \multicolumn{2}{|c|}{$\begin{array}{l}\text { Oral } \\
(n=1674)\end{array}$} & \multicolumn{2}{|c|}{$\begin{array}{l}\text { IV } \\
(n=318)\end{array}$} \\
\hline & $\mathrm{n}$ & $\%$ & $\mathrm{n}$ & $\%$ & $\mathrm{n}$ & $\%$ & $\mathrm{n}$ & $\%$ \\
\hline Bone & 469 & 26.8 & 85 & 36.5 & 479 & 28.6 & 76 & 23.9 \\
\hline Others & 696 & 39.7 & 100 & 42.9 & 704 & 42.1 & 97 & 30.5 \\
\hline \multicolumn{9}{|l|}{ Nephrectomy prior to treatment } \\
\hline Any nephrectomy & 395 & 22.6 & 47 & 20.2 & 390 & 23.3 & 53 & 16.7 \\
\hline Cytoreductive nephrectomy & 380 & 21.7 & 41 & 17.6 & 377 & 22.5 & 45 & 14.2 \\
\hline
\end{tabular}

Data are $\mathrm{n}$ and \% unless otherwise indicated. CHF congestive heart failure, CKD chronic kidney disease, COPD chronic obstructive pulmonary disease, DCCI DeyoCharlson Comorbidity Index, HMO health maintenance organization, $P O S$ point-of-service, $P P O$ preferred provider organization, $Q$ quartile

Treatment patterns are included in Table 3. A total of 1752 patients $(88 \%)$ received TK/VEGF inhibitor treatment, 233 (12\%) received mTOR inhibitor treatment, 1674 (84\%) received oral treatment and $318(16 \%)$ received IV treatment. The most common $1 \mathrm{~L}$ treatment was sunitinib $(n=849)$, followed by pazopanib $(n=631)$, temsirolimus $(n=157)$ and bevacizumab $(n=149)$. A total of 154 patients were treated with bevacizumab, but only $3 \%(n=5)$ received bevacizumab in combination with IFN- $\alpha$. Baseline characteristics by agent are shown in Additional file 1: Tables S2 to S4.

Factors potentially associated with drug class or route of administration were evaluated. Multivariate analyses comparing baseline characteristics of patients treated with TK/VEGF and mTOR inhibitors showed that patients with either baseline congestive heart failure (CHF), secondary bone metastases or secondary liver metastases and those who started $1 \mathrm{~L}$ treatment in 2011 or 2012 (vs 2015) were more likely to receive mTOR inhibitors (Fig. 3a). Conversely, patients with baseline diabetes were more likely to receive TK/VEGF-directed agents than those without (Fig. 3a). In multivariate analyses comparing oral vs IV treatments, patients who had baseline secondary lung metastases or other baseline metastases (other than lung/liver/brain/bone) were more likely to receive oral therapy than those who did not. Non-retired patients and those who started $1 \mathrm{~L}$ treatment in 2011 or 2012 (vs 2015) were more likely to receive IV than oral treatment (Fig. 3b).

\section{$1 \mathrm{~L}$ treatment duration, $\mathrm{TT} 2 \mathrm{~T}$ and characterization of $2 \mathrm{~L}$ treatments: longitudinal analysis}

Among the 1992 patients treated with $1 \mathrm{~L}$ targeted therapy, the median duration of $1 \mathrm{~L}$ treatment was 5.9 months (Table 3). The median duration of $1 \mathrm{~L}$ TK/VEGF-directed (6.3 months) or oral (6.6 months) treatment was longer than that of $1 \mathrm{~L}$ mTOR-directed (3.9 months) or IV (3.4 months) treatment. The median

Table $31 \mathrm{~L}$ treatment patterns, duration and TT2T switch: drug class, administration route and agents

\begin{tabular}{|c|c|c|c|}
\hline $1 \mathrm{~L}$ treatment & Patients, n & Median duration of $1 \mathrm{~L}$ treatment $(95 \% \mathrm{Cl})$, months ${ }^{a}$ & Median TT2T $(95 \% \mathrm{Cl})$, months ${ }^{a}$ \\
\hline All patients & 1992 & $5.9(5.5,6.4)$ & $9.1(8.5,10.0)$ \\
\hline \multicolumn{4}{|l|}{ Class } \\
\hline TKNEGF inhibitor & 1752 & $6.3(5.8,6.7)$ & $9.8(8.9,10.4)$ \\
\hline mTOR inhibitor & 233 & $3.9(3.4,4.8)$ & $6.0(4.6,7.1)$ \\
\hline \multicolumn{4}{|l|}{ Route of administration } \\
\hline Oral & 1674 & $6.6(6.0,7.3)$ & $9.4(8.6,10.2)$ \\
\hline IV & 318 & $3.4(2.7,3.9)$ & $7.3(6.0,9.9)$ \\
\hline \multicolumn{4}{|l|}{ Agent } \\
\hline Sunitinib (TK; oral) & 849 & $6.5(5.9,7.6)$ & $9.4(8.5,10.3)$ \\
\hline Sorafenib (TK; oral) & 62 & $4.7(3.3,9.8)$ & $8.4(4.8,12.6)$ \\
\hline Pazopanib (TK; oral) & 631 & $7.0(6.0,8.0)$ & $9.3(8.2,10.6)$ \\
\hline Axitinib (TK; oral) & 56 & $12.0(7.4,18.8)$ & $14.4(7.7,22.3)$ \\
\hline Bevacizumab (VEGF; IV) & 149 & $2.8(1.8,4.4)$ & $22.5(11.7, \mathrm{NR})$ \\
\hline Everolimus (mTOR; oral) & 76 & $4.0(3.2,6.1)$ & $8.0(3.6,11.3)$ \\
\hline Temsirolimus (mTOR; IV) & 157 & $3.9(3.0,4.8)$ & $5.7(4.3,6.7)$ \\
\hline
\end{tabular}

a Kaplan-Meier methods were used. NR not reached 


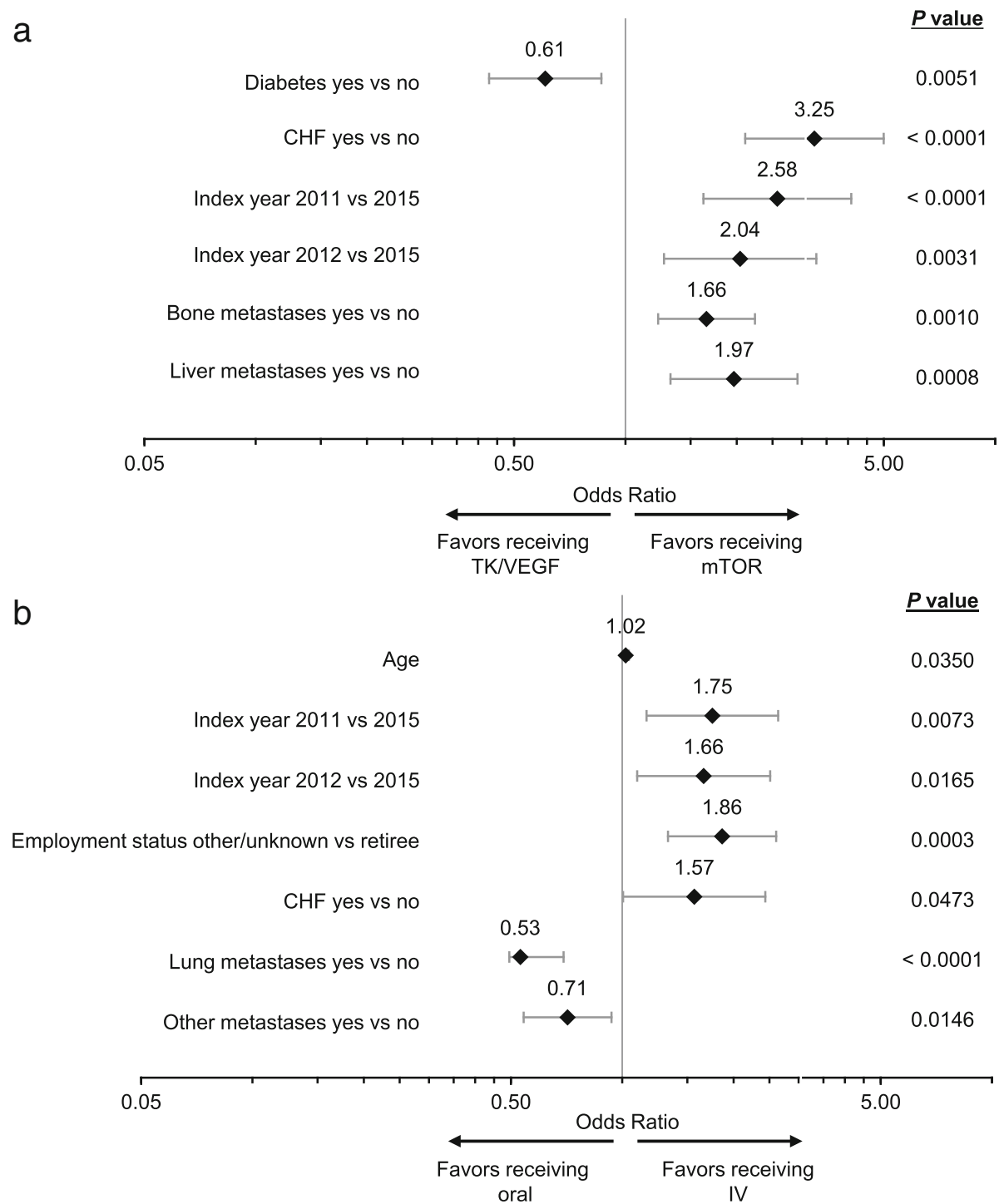

Fig. 3 Multivariate analysis. a Odds of receiving 1 L mTOR vs TKNEGF inhibitors. $\mathbf{b}$ Odds of receiving IV vs orally administered treatment. Only variables found to be significant are plotted. Other variables in the multivariate analysis for the comparison of TKNEGF inhibitor treatment vs mTOR inhibitor treatment were not significantly different (age, sex, index years 2013 and 2014 vs 2015, DCCl and nephrectomy). Other variables in the multivariate analysis for the comparison of oral vs IV administration that did not reach statistical significance were sex, employment status (active and long-term disability vs retiree), insurance type, DCCl, index years 2013 and 2014 vs 2015 and nephrectomy)

TT2T was 9.1 months (Table 3). Among the oral agents, axitinib had the longest median treatment duration (12.0 months) and median TT2T (14.4 months); everolimus had the shortest median treatment duration $(4.0$ months) and median TT2T (8.0 months). Among the IV agents, the median treatment durations of temsirolimus and bevacizumab were 3.9 and 2.8 months, respectively. The median TT2T was 5.7 months for temsirolimus and 22.5 months for bevacizumab (Table 3). The flow of treatment across lines of therapy is shown in Fig. 4. Of the 1992 patients who received $1 \mathrm{~L}$ treatment, $52.8 \%$ $(n=1052)$ received a $2 \mathrm{~L}$ treatment. The median follow-up durations in patients who did and did not receive $2 \mathrm{~L}$ treatment were 17.2 and 14.4 months, respectively. Everolimus was the $2 \mathrm{~L}$ drug of choice $(15.2 \%$ of all 1992 evaluated patients), followed by axitinib (10.7\%) and nivolumab (4.6\%). Overall, $28 \%$ of all patients received $2 \mathrm{~L}$ TK/VEGF-directed therapy, and $20 \%$ received $2 \mathrm{~L}$ mTOR-targeted therapy. Forty-one percent of patients received oral $2 \mathrm{~L}$ therapy, and $12 \%$ received IV $2 \mathrm{~L}$ therapy (including nivolumab).

\section{IR and time to potentially treatment-related AEs: longitudinal analysis}

The three most common, potentially treatment-related AEs occurring during or up to 30 days after $1 \mathrm{~L}$ 


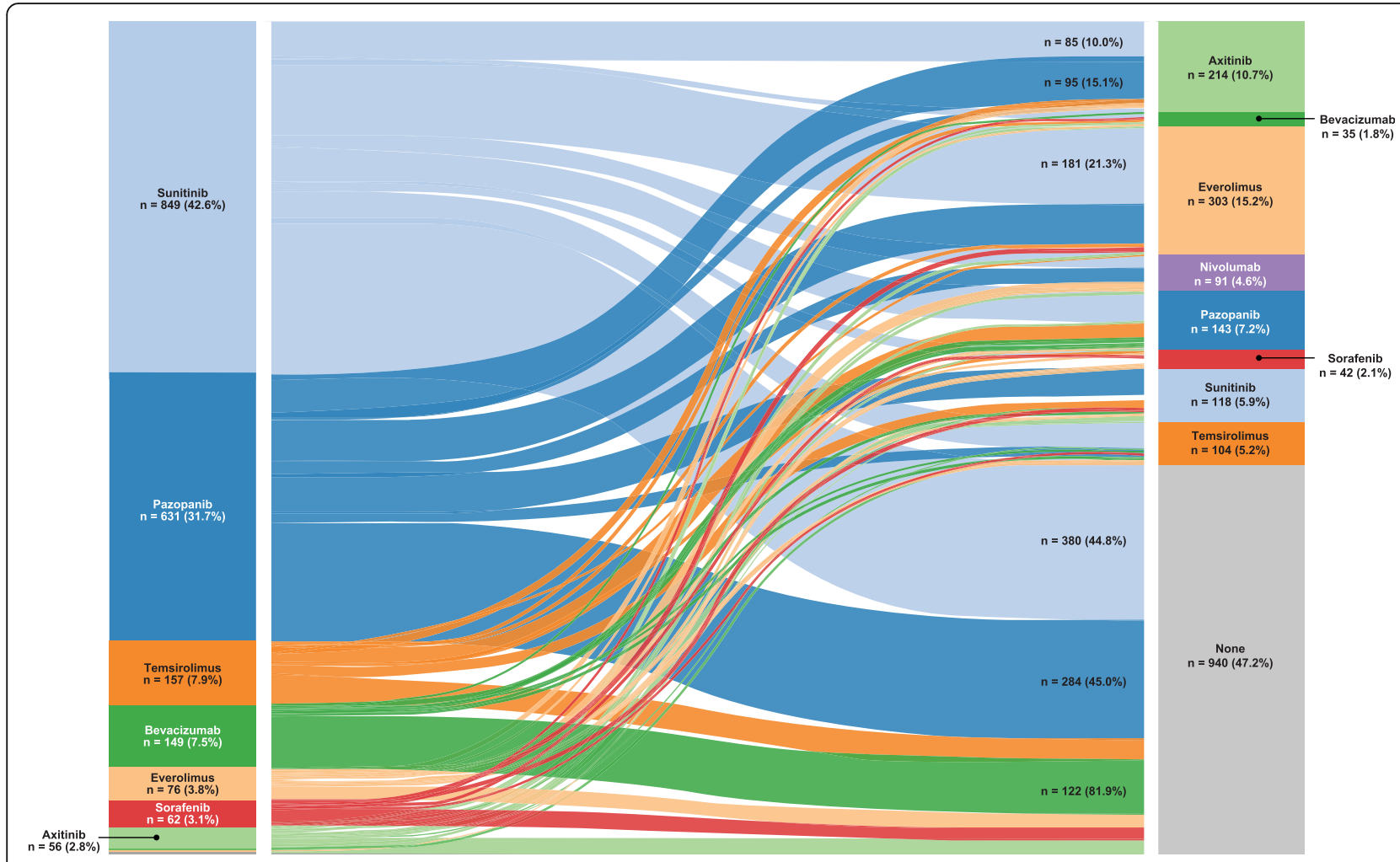

Fig. $41 \mathrm{~L}$ to $2 \mathrm{~L}$ treatment flow in patients with mRCC in the Truven Health MarketScan databases. Possible reasons for patients not receiving $2 \mathrm{~L}$ treatment include still being on $1 \mathrm{~L}$ treatment, no requirement for $2 \mathrm{~L}$ treatment, refusal of treatment and death, although these cannot be reliably obtained from the claims database

treatment were nausea/vomiting (127.2 per $100 \mathrm{PY})$, hypertension (69.1 per $100 \mathrm{PY}$ ) and renal insufficiency (44.5 per 100 PY) (Table 4). In addition to nausea/vomiting and renal insufficiency, hypertension (in patients who received oral treatment and those treated with TK/ VEGF inhibitors) and anemia (in patients who received IV treatment and those treated with mTOR-directed therapy) were among the four most common AEs when evaluated separately by treatment categories.

Based on time between the claims indicating the initiation of a drug and the initial $\mathrm{AE}$ that may have required medical attention, substantial latency of onset (median time to first AE claim) was observed for several potentially treatment-related toxicities in patients treated with $1 \mathrm{~L}$ TK/VEGF-directed treatment, including nausea/ vomiting (21 days), fatigue/asthenia (72 days), thyroid disorders (133 days), abdominal pain (99 days), diarrhea (108 days), pneumonitis (83 days), hepatitis (154 days), adrenal insufficiency (119 days), neutropenia (110 days) and colitis (97 days) (Table 5).

\section{Discussion}

As the number of $1 \mathrm{~L}$ and $2 \mathrm{~L}$ treatment options for $\mathrm{mRCC}$ increases, and the role of effective sequencing of agents evolves, a thorough understanding of the treatment patterns and $\mathrm{AE}$ profiles of each drug class in the real-world setting will be critical to providing medical benchmarks, assessing adherence to guidelines and informing benefit:risk decisions in selecting the appropriate $\mathrm{mRCC}$ treatment. This retrospective, claims-based analysis evaluated treatment patterns and AEs among a large, real-world, US population of patients with mRCC. A cross-sectional analysis was performed to better understand the patterns of $1 \mathrm{~L}$ treatment initiation over a 10-year period, and a longitudinal analysis provided information of treatment choice, baseline correlates and associated AEs in patients treated in routine medical practice.

The cross-sectional trend analysis demonstrated that $1 \mathrm{~L}$ treatment initiation patterns for mRCC generally reflected the US Food and Drug Administration approvals and NCCN treatment guidelines, with a few exceptions. The rapid uptake of the TK-targeting agents sunitinib (approved in 2006) and pazopanib (approved in 2009) was noted, establishing TK/VEGF-directed treatment as the most widely prescribed drug class initiated during the study period. Throughout the study period, oral treatments were also more commonly used than IV treatments. These patterns of TK/VEGF inhibitors and oral agents were also recapitulated in the longitudinal 
Table 4 AE IRs in patients with mRCC by drug class and administration route

\begin{tabular}{|c|c|c|c|c|c|}
\hline \multirow{2}{*}{$\begin{array}{l}\text { Potentially treatment-related } \\
\text { AEs during or }<30 \text { days after } \\
1 \mathrm{~L} \text { treatment }^{\mathrm{a}}\end{array}$} & $\begin{array}{l}\text { All patients } \\
(N=1992)\end{array}$ & \multirow{2}{*}{$\begin{array}{l}\text { TKNEGF inhibitor } \\
(n=1752) \\
\text { IR per } 100 \text { PYa } \\
\text { (Poisson } 95 \% \mathrm{Cl})\end{array}$} & \multirow{2}{*}{$\begin{array}{l}\text { mTOR inhibitor } \\
(n=233) \\
\text { IR per } 100 \mathrm{PY}^{\mathrm{a}} \\
\text { (Poisson } 95 \% \mathrm{Cl})\end{array}$} & \multirow{2}{*}{$\begin{array}{l}\text { Oral } \\
(n=1674) \\
\text { IR per } 100 \mathrm{PY}^{\mathrm{a}} \\
\text { (Poisson 95\% Cl) }\end{array}$} & \multirow{2}{*}{$\begin{array}{l}\text { IV } \\
(n=318) \\
\text { IR per } 100 \mathrm{PY}^{\mathrm{a}} \\
\text { (Poisson } 95 \% \mathrm{Cl})\end{array}$} \\
\hline & $\begin{array}{l}\text { IR per } 100 \mathrm{PY}^{\mathrm{a}} \\
\text { (Poisson 95\% Cl) }\end{array}$ & & & & \\
\hline Fatigue/asthenia & $\begin{array}{l}39.8 \\
(36.3,43.6)\end{array}$ & $\begin{array}{l}38.2 \\
(34.5,42.0)\end{array}$ & $\begin{array}{l}55.2 \\
(41.7,70.5)\end{array}$ & $\begin{array}{l}38.7 \\
(34.9,42.6)\end{array}$ & $\begin{array}{l}49.3 \\
(37.8,62.3)\end{array}$ \\
\hline Hypertension & $\begin{array}{l}69.1 \\
(61.3,77.4)\end{array}$ & $\begin{array}{l}71.7 \\
(63.3,80.7)\end{array}$ & $\begin{array}{l}47.8 \\
(29.2,71.0)\end{array}$ & $\begin{array}{l}70.2 \\
(61.9,79.0)\end{array}$ & $\begin{array}{l}59.2 \\
(37.9,85.2)\end{array}$ \\
\hline Diarrhea & $\begin{array}{l}28.5 \\
(25.6,31.6)\end{array}$ & $\begin{array}{l}29.9 \\
(26.7,33.2)\end{array}$ & $\begin{array}{l}13.1 \\
(7.3,20.5)\end{array}$ & $\begin{array}{l}30.7 \\
(27.5,34.1)\end{array}$ & $\begin{array}{l}13.2 \\
8.0,19.5)\end{array}$ \\
\hline Hand-foot syndrome & $\begin{array}{l}4.1 \\
(3.1,5.2)\end{array}$ & $\begin{array}{l}4.0 \\
(3.0,5.2)\end{array}$ & $\begin{array}{l}3.1 \\
(0.9,6.9)\end{array}$ & $\begin{array}{l}4.0 \\
(3.0,5.2)\end{array}$ & $\begin{array}{l}4.4 \\
(1.8,8.3)\end{array}$ \\
\hline Dyspnea & $\begin{array}{l}37.6 \\
(34.1,41.2)\end{array}$ & $\begin{array}{l}34.7 \\
(31.3,38.4)\end{array}$ & $\begin{array}{l}69.6 \\
(53.4,88.0)\end{array}$ & $\begin{array}{l}35.9 \\
(32.3,39.6)\end{array}$ & $\begin{array}{l}51.7 \\
(39.9,65.0)\end{array}$ \\
\hline Nausea/vomiting & $\begin{array}{l}127.2 \\
(119.0,135.6)\end{array}$ & $\begin{array}{l}114.2 \\
(106.3,122.4)\end{array}$ & $\begin{array}{l}364.5 \\
(304.6,429.8)\end{array}$ & $\begin{array}{l}119.1 \\
(110.8,127.6)\end{array}$ & $\begin{array}{l}209.7 \\
(175.6,246.8)\end{array}$ \\
\hline Back pain & $\begin{array}{l}19.9 \\
(17.5,22.4)\end{array}$ & $\begin{array}{l}20.3 \\
(17.8,23.0)\end{array}$ & $\begin{array}{l}16.2 \\
(9.7,24.2)\end{array}$ & $\begin{array}{l}19.8 \\
(17.3,22.5)\end{array}$ & $\begin{array}{l}20.8 \\
(14.0,28.9)\end{array}$ \\
\hline Pain in extremity/limb discomfort & $\begin{array}{l}27.8 \\
(24.9,30.8)\end{array}$ & $\begin{array}{l}26.6 \\
(23.6,29.7)\end{array}$ & $\begin{array}{l}40.9 \\
(29.6,54.0)\end{array}$ & $\begin{array}{l}27.1 \\
(24.1,30.3)\end{array}$ & $\begin{array}{l}33.0 \\
(24.1,43.4)\end{array}$ \\
\hline Abdominal pain & $\begin{array}{l}31.2 \\
(28.1,34.5)\end{array}$ & $\begin{array}{l}30.6 \\
(27.4,34.0)\end{array}$ & $\begin{array}{l}35.8 \\
(25.1,48.4)\end{array}$ & $\begin{array}{l}32.0 \\
(28.7,35.6)\end{array}$ & $\begin{array}{l}25.0 \\
(17.3,34.1)\end{array}$ \\
\hline Anemia & $\begin{array}{l}40.3 \\
(36.6,44.1)\end{array}$ & $\begin{array}{l}35.4 \\
(31.8,39.1)\end{array}$ & $\begin{array}{l}100.3 \\
(79.1,123.9)\end{array}$ & $\begin{array}{l}37.9 \\
(34.1,41.8)\end{array}$ & $\begin{array}{l}61.6 \\
(48.0,76.9)\end{array}$ \\
\hline Hypophosphatemia & $\begin{array}{l}1.7 \\
(1.1,2.5)\end{array}$ & $\begin{array}{l}1.5 \\
(0.9,2.2)\end{array}$ & $\begin{array}{l}2.3 \\
(0.5,5.6)\end{array}$ & $\begin{array}{l}1.5 \\
(0.9,2.3)\end{array}$ & $\begin{array}{l}3.1 \\
(1.0,6.4)\end{array}$ \\
\hline Neutropenia & $\begin{array}{l}3.9 \\
(3.0,5.0)\end{array}$ & $\begin{array}{l}4.2 \\
(3.1,5.3)\end{array}$ & $\begin{array}{l}1.6 \\
(0.2,4.3)\end{array}$ & $\begin{array}{l}4.2 \\
(3.1,5.4)\end{array}$ & $\begin{array}{l}1.9 \\
(0.4,4.5)\end{array}$ \\
\hline Lymphopenia & $\begin{array}{l}0.2 \\
(0.0,0.5)\end{array}$ & $\begin{array}{l}0.1 \\
(0.0,0.3)\end{array}$ & $\begin{array}{l}1.6 \\
(0.2,4.3)\end{array}$ & $\begin{array}{l}0.2 \\
(0.0,0.4)\end{array}$ & $\begin{array}{l}0.6 \\
(0.0,2.3)\end{array}$ \\
\hline Hypotension & $\begin{array}{l}7.7 \\
(6.3,9.3)\end{array}$ & $\begin{array}{l}7.6 \\
(6.2,9.2)\end{array}$ & $\begin{array}{l}7.2 \\
(3.3,12.7)\end{array}$ & $\begin{array}{l}7.6 \\
(6.1,9.3)\end{array}$ & $\begin{array}{l}8.6 \\
(4.6,13.8)\end{array}$ \\
\hline Proteinuria & $\begin{array}{l}5.2 \\
(4.1,6.5)\end{array}$ & $\begin{array}{l}5.0 \\
(3.9,6.3)\end{array}$ & $\begin{array}{l}7.3 \\
(3.4,12.9)\end{array}$ & $\begin{array}{l}4.7 \\
(3.6,5.9)\end{array}$ & $\begin{array}{l}9.8 \\
(5.5,15.4)\end{array}$ \\
\hline Thrombocytopenia & $\begin{array}{l}3.0 \\
(2.2,3.9)\end{array}$ & $\begin{array}{l}3.0 \\
(2.2,4.1)\end{array}$ & $\begin{array}{l}2.3 \\
(0.5,5.6)\end{array}$ & $\begin{array}{l}3.1 \\
(2.2,4.1)\end{array}$ & $\begin{array}{l}1.9 \\
(0.4,4.5)\end{array}$ \\
\hline Hepatitis & $\begin{array}{l}9.3 \\
(7.7,11.1)\end{array}$ & $\begin{array}{l}9.1 \\
(7.5,11.0)\end{array}$ & $\begin{array}{l}11.0 \\
(5.7,18.1)\end{array}$ & $\begin{array}{l}9.7 \\
(7.9,11.6)\end{array}$ & $\begin{array}{l}6.3 \\
(2.9,11.0)\end{array}$ \\
\hline Thyroid disorders & $\begin{array}{l}21.2 \\
(18.6,24.0)\end{array}$ & $\begin{array}{l}21.9 \\
(19.1,24.9)\end{array}$ & $\begin{array}{l}14.9 \\
(8.5,23.0)\end{array}$ & $\begin{array}{l}22.9 \\
(20.0,26.0)\end{array}$ & $\begin{array}{l}9.5 \\
(5.0,15.3)\end{array}$ \\
\hline Renal insufficiency & $\begin{array}{l}44.5 \\
(38.9,50.5)\end{array}$ & $\begin{array}{l}42.3 \\
(36.6,48.4)\end{array}$ & $\begin{array}{l}60.8 \\
(38.9,87.4)\end{array}$ & $\begin{array}{l}43.0 \\
(37.2,49.3)\end{array}$ & $\begin{array}{l}58.3 \\
(39.0,81.3)\end{array}$ \\
\hline Adrenal insufficiency & $\begin{array}{l}6.3 \\
(5.0,7.7)\end{array}$ & $\begin{array}{l}5.8 \\
(4.5,7.2)\end{array}$ & $\begin{array}{l}10.4 \\
(5.4,17.0)\end{array}$ & $\begin{array}{l}5.9 \\
(4.6,7.4)\end{array}$ & $\begin{array}{l}9.1 \\
(4.8,14.6)\end{array}$ \\
\hline Pneumonitis & $\begin{array}{l}27.3 \\
(24.4,30.2)\end{array}$ & $\begin{array}{l}24.6 \\
(21.8,27.6)\end{array}$ & $\begin{array}{l}56.2 \\
(42.4,71.8)\end{array}$ & $\begin{array}{l}25.2 \\
(22.4,28.3)\end{array}$ & $\begin{array}{l}43.6 \\
(33.3,55.3)\end{array}$ \\
\hline Colitis & $\begin{array}{l}0.5 \\
(0.2,0.9)\end{array}$ & $\begin{array}{l}0.5 \\
(0.2,0.9)\end{array}$ & $\begin{array}{l}0.8 \\
(0.0,2.9)\end{array}$ & $\begin{array}{l}0.4 \\
(0.1,0.8)\end{array}$ & $\begin{array}{l}1.3 \\
(0.2,3.5)\end{array}$ \\
\hline Guillain-Barré syndrome & $\begin{array}{l}0.1 \\
(0.0,0.3)\end{array}$ & $\begin{array}{l}0.1 \\
(0.0,0.3)\end{array}$ & 0 & $\begin{array}{l}0.1 \\
(0.0,0.3)\end{array}$ & 0 \\
\hline Meningoencephalitis & $\begin{array}{l}0.5 \\
(0.2,0.9)\end{array}$ & $\begin{array}{l}0.5 \\
(0.2,1.0)\end{array}$ & 0 & $\begin{array}{l}0.5 \\
(0.2,0.9)\end{array}$ & $\begin{array}{l}0.6 \\
(0.0,2.3)\end{array}$ \\
\hline Myasthenia gravis & 0 & 0 & 0 & 0 & 0 \\
\hline Rash & $\begin{array}{l}10.1 \\
(8.5,11.9)\end{array}$ & $\begin{array}{l}9.5 \\
(7.9,11.3)\end{array}$ & $\begin{array}{l}14.3 \\
(8.4,21.9)\end{array}$ & $\begin{array}{l}9.9 \\
(8.2,11.7)\end{array}$ & $\begin{array}{l}11.9 \\
(7.1,18.0)\end{array}$ \\
\hline
\end{tabular}

a Washout period of 30 days prior to the index date was applied when identifying incidence events for all AEs, except for chronic conditions, where a 365-day washout period was applied. If a patient did not have an event, their person-time was counted up to 30 days after the end of first-line treatment or the end of eligibility, whichever occurred first 
Table 5 Time to onset of AEs by drug class and route of administration

\begin{tabular}{|c|c|c|c|c|c|}
\hline \multirow[t]{2}{*}{ Adverse event } & \multirow{2}{*}{$\begin{array}{l}\text { All patients } \\
(N=1992) \\
\text { Median, days } \\
(\mathrm{Q} 1-\mathrm{Q} 3)\end{array}$} & \multirow{2}{*}{$\begin{array}{l}\text { TKVEGF inhibitor } \\
(n=1752) \\
\text { Median, days } \\
\text { (Q1-Q3) }\end{array}$} & \multirow{2}{*}{$\begin{array}{l}\text { mTOR inhibitor } \\
(n=233) \\
\text { Median, days } \\
\text { (Q1-Q3) }\end{array}$} & \multirow{2}{*}{$\begin{array}{l}\text { Oral } \\
(n=1674) \\
\text { Median, days } \\
\text { (Q1-Q3) }\end{array}$} & \multirow{2}{*}{$\begin{array}{l}\text { IV } \\
(n=318) \\
\text { Median, days } \\
(\mathrm{Q} 1-\mathrm{Q} 3)\end{array}$} \\
\hline & & & & & \\
\hline Fatigue/asthenia & $\begin{array}{l}72.0 \\
(29.0,157.0)\end{array}$ & $\begin{array}{l}74.0 \\
(28.0,168.0)\end{array}$ & $\begin{array}{l}63.0 \\
(35.5,119.0)\end{array}$ & $\begin{array}{l}74.0 \\
(28.0,165.0)\end{array}$ & $\begin{array}{l}58.5 \\
(29.0,118.0)\end{array}$ \\
\hline Hypertension & $\begin{array}{l}72.0 \\
(28.0,156.0)\end{array}$ & $\begin{array}{l}70.0 \\
(28.0,151.0)\end{array}$ & $\begin{array}{l}116.5 \\
(42.0,240.5)\end{array}$ & $\begin{array}{l}72.0 \\
(29.0,163.0)\end{array}$ & $\begin{array}{l}76.5 \\
(11.5,138.5)\end{array}$ \\
\hline Diarrhea & $\begin{array}{l}108.0 \\
(45.0,211.0)\end{array}$ & $\begin{array}{l}111.0 \\
(48.5,215.5)\end{array}$ & $\begin{array}{l}46.0 \\
(25.0,194.0)\end{array}$ & $\begin{array}{l}110.0 \\
(48.0,214.0)\end{array}$ & $\begin{array}{l}46.5 \\
(21.5,194.5)\end{array}$ \\
\hline Hand-foot syndrome & $\begin{array}{l}93.5 \\
(43.0,218.0)\end{array}$ & $\begin{array}{l}109.0 \\
(54.0,231.5 .0)\end{array}$ & $\begin{array}{l}30.0 \\
(20.5,53.0)\end{array}$ & $\begin{array}{l}112.0 \\
(57.0,241.0)\end{array}$ & $\begin{array}{l}30.0 \\
(10.0,33.0)\end{array}$ \\
\hline Dyspnea & $\begin{array}{l}88.0 \\
(28.0,210.0)\end{array}$ & $\begin{array}{l}94.0 \\
(29.0,227.0)\end{array}$ & $\begin{array}{l}68.5 \\
(23.0,156.0)\end{array}$ & $\begin{array}{l}95.0 \\
(31.0,226.0)\end{array}$ & $\begin{array}{l}52.0 \\
(20.0,146.0)\end{array}$ \\
\hline Nausea/vomiting & $\begin{array}{l}21.0 \\
(4.0,78.0)\end{array}$ & $\begin{array}{l}27.0 \\
(7.0,89.0)\end{array}$ & 0 & $\begin{array}{l}28.0 \\
(8.0,90.0)\end{array}$ & 0 \\
\hline Back pain & $\begin{array}{l}90.0 \\
(31.0,198.0)\end{array}$ & $\begin{array}{l}90.5 \\
(34.0,197.50)\end{array}$ & $\begin{array}{l}89.0 \\
(22.0,287.0)\end{array}$ & $\begin{array}{l}93.0 \\
(34.0,198.0)\end{array}$ & $\begin{array}{l}75.0 \\
(20.0,196.0)\end{array}$ \\
\hline Pain in extremity/limb discomfort & $\begin{array}{l}112.0 \\
(46.0,238.0)\end{array}$ & $\begin{array}{l}113.0 \\
(44.0,238.0)\end{array}$ & $\begin{array}{l}95.0 \\
(48.0,240.0)\end{array}$ & $\begin{array}{l}113.0 \\
(46.5,246.0)\end{array}$ & $\begin{array}{l}83.0 \\
(44.0,165.0)\end{array}$ \\
\hline Abdominal pain & $\begin{array}{l}98.5 \\
(35.0,226.5)\end{array}$ & $\begin{array}{l}104.5 \\
(36.0,229.0)\end{array}$ & $\begin{array}{l}87.0 \\
(32.5,195.0)\end{array}$ & $\begin{array}{l}104.5 \\
(37.0,229.0)\end{array}$ & $\begin{array}{l}63.5 \\
(30.0,176.0)\end{array}$ \\
\hline Anemia & $\begin{array}{l}85.0 \\
(32.5,183.5)\end{array}$ & $\begin{array}{l}93.0 \\
(35.0,200.0)\end{array}$ & $\begin{array}{l}66.0 \\
(26.0,132.0)\end{array}$ & $\begin{array}{l}93.5 \\
(35.0,201.0)\end{array}$ & $\begin{array}{l}64.5 \\
(18.0,118.0)\end{array}$ \\
\hline Hypophosphatemia & $\begin{array}{l}100.0 \\
(56.0,138.0)\end{array}$ & $\begin{array}{l}102.0 \\
(60.0,136.5)\end{array}$ & $\begin{array}{l}299.0 \\
(43.0,498.0)\end{array}$ & $\begin{array}{l}110.0 \\
(60.0,146.0)\end{array}$ & $\begin{array}{l}43.0 \\
(9.0,104.0)\end{array}$ \\
\hline Neutropenia & $\begin{array}{l}110.0 \\
(47.5,242.5)\end{array}$ & $\begin{array}{l}117.0 \\
(48.0,245.0)\end{array}$ & $\begin{array}{l}37.5 \\
(19.0,56.0)\end{array}$ & $\begin{array}{l}115.0 \\
(48.0,240.0)\end{array}$ & $\begin{array}{l}56.0 \\
(19.0,465.0)\end{array}$ \\
\hline Lymphopenia & $\begin{array}{l}108.0 \\
(95.0,136.0)\end{array}$ & $\begin{array}{l}95.0 \\
(95.0,95.0)\end{array}$ & $\begin{array}{l}122.0 \\
(108.0,136.0)\end{array}$ & $\begin{array}{l}115.5 \\
(95.0,136.0)\end{array}$ & $\begin{array}{l}108.0 \\
(108.0,108.0)\end{array}$ \\
\hline Hypotension & $\begin{array}{l}105.0 \\
(42.0,222.0)\end{array}$ & $\begin{array}{l}117.5 \\
(44.0,239.0)\end{array}$ & $\begin{array}{l}58.0 \\
(51.0,179.0)\end{array}$ & $\begin{array}{l}111.0 \\
(43.0,230.0)\end{array}$ & $\begin{array}{l}56.0 \\
(41.0,191.0)\end{array}$ \\
\hline Proteinuria & $\begin{array}{l}80.5 \\
(29.0,245.0)\end{array}$ & $\begin{array}{l}84.0 \\
(30.0,235.0)\end{array}$ & $\begin{array}{l}56.0 \\
(26.0,257.0)\end{array}$ & $\begin{array}{l}108.0 \\
(41.0,336.0)\end{array}$ & $\begin{array}{l}30.0 \\
(20.0,84.0)\end{array}$ \\
\hline Thrombocytopenia & $\begin{array}{l}97.0 \\
(50.0,188.0)\end{array}$ & $\begin{array}{l}93.5 \\
(48.5,194.0)\end{array}$ & $\begin{array}{l}112.0 \\
(52.0,140.0)\end{array}$ & $\begin{array}{l}87.0 \\
(48.5,187.0)\end{array}$ & $\begin{array}{l}140.0 \\
(112.0,256.0)\end{array}$ \\
\hline Hepatitis & $\begin{array}{l}154.0 \\
(71.0,256.0)\end{array}$ & $\begin{array}{l}148.0 \\
(71.0,253.0)\end{array}$ & $\begin{array}{l}209.0 \\
(128.0,326.0)\end{array}$ & $\begin{array}{l}150.5 \\
(71.0,256.0)\end{array}$ & $\begin{array}{l}190.0 \\
(166.0,234.0)\end{array}$ \\
\hline Thyroid disorders & $\begin{array}{l}133.0 \\
(75.0,256.0)\end{array}$ & $\begin{array}{l}134.0 \\
(79.0,259.0)\end{array}$ & $\begin{array}{l}91.0 \\
(55.0,196.0)\end{array}$ & $\begin{array}{l}133.5 \\
(79.0,259.0)\end{array}$ & $\begin{array}{l}131.0 \\
(62.0,175.0)\end{array}$ \\
\hline Renal insufficiency & $\begin{array}{l}94.0 \\
(33.0,217.0)\end{array}$ & $\begin{array}{l}95.0 \\
(39.5,225.5)\end{array}$ & $\begin{array}{l}90.5 \\
(18.0,62.5)\end{array}$ & $\begin{array}{l}97.0 \\
(41.0,231.0)\end{array}$ & $\begin{array}{l}61.0 \\
(14.0,133.0)\end{array}$ \\
\hline Adrenal insufficiency & $\begin{array}{l}119.0 \\
(69.0,213.0)\end{array}$ & $\begin{array}{l}108.0 \\
(67.0,227.0)\end{array}$ & $\begin{array}{l}147.0 \\
(118.0,200.0)\end{array}$ & $\begin{array}{l}110.0 \\
(70.0,218.0)\end{array}$ & $\begin{array}{l}132.0 \\
(4.0,201.0)\end{array}$ \\
\hline Pneumonitis & $\begin{array}{l}83.0 \\
(29.0,209.0)\end{array}$ & $\begin{array}{l}87.0 \\
(31.0,223.0)\end{array}$ & $\begin{array}{l}73.5 \\
(21.5,155.5)\end{array}$ & $\begin{array}{l}90.0 \\
(31.0,223.0)\end{array}$ & $\begin{array}{l}68.5 \\
(19.5,150.5)\end{array}$ \\
\hline Colitis & $\begin{array}{l}97.0 \\
(43.0,139.0)\end{array}$ & $\begin{array}{l}101.5 \\
(66.0,139.0)\end{array}$ & 0 & $\begin{array}{l}106.0 \\
(97.0,139.0)\end{array}$ & $\begin{array}{l}21.5 \\
(0.0,43.0)\end{array}$ \\
\hline Guillain-Barré syndrome & $\begin{array}{l}52.0 \\
(52.0,52.0)\end{array}$ & $\begin{array}{l}52.0 \\
(52.0,52.0)\end{array}$ & 0 & $\begin{array}{l}52.0 \\
(52.0,52.0)\end{array}$ & 0 \\
\hline Meningoencephalitis & $\begin{array}{l}122.0 \\
(75.0,159.0)\end{array}$ & $\begin{array}{l}122.0 \\
(75.0,159.0)\end{array}$ & 0 & $\begin{array}{l}112.0 \\
(75.0,159.0)\end{array}$ & $\begin{array}{l}122.0 \\
(122.0,122.0\end{array}$ \\
\hline Myasthenia gravis & 0 & 0 & 0 & 0 & 0 \\
\hline Rash & $\begin{array}{l}79.0 \\
(37.5,214.0)\end{array}$ & $\begin{array}{l}83.0 \\
(44.0,220.0)\end{array}$ & $\begin{array}{l}55.0 \\
(23.0,149.0)\end{array}$ & $\begin{array}{l}82.5 \\
(47.0,213.0)\end{array}$ & $\begin{array}{l}28.0 \\
(10.0,224.0)\end{array}$ \\
\hline
\end{tabular}


analysis. These findings are consistent with those from studies detailing the widespread use of TK inhibitors [26], and the less frequent use of sorafenib and axitinib in the $1 \mathrm{~L}$ setting is also consistent with NCCN recommendations for these TK inhibitors [8]. Of note was the finding that the use of bevacizumab as monotherapy was more prevalent than as combination therapy with IFN- $\alpha$. These findings suggest that increased costs and IFN-related toxicities may render bevacizumab more attractive as monotherapy than as combination therapy with IFN [27]. Moreover, Phase II data support the use of bevacizumab as $1 \mathrm{~L}$ treatment and salvage therapy [28, 29]. Additionally, a considerable number of patients received everolimus in the $1 \mathrm{~L}$ setting despite the lack of indication in this setting, which reflects the wide variability seen in provider preference and clinical experience.

Provider preferences, patient history and known toxicities associated with drug classes may drive $1 \mathrm{~L}$ treatment choice, although it is difficult to ascertain from claims data which characteristics influenced the specific choices of mRCC treatment. In this study, CHF and a DCCI score $\geq 4$ were independent predictors of IV treatment choice, while patients with lung metastases were less likely to receive IV treatment than were those without lung metastases. Patients with diabetes were less likely to receive mTOR-directed therapy, while patients with comorbid CHF, liver metastases or bone metastases were more likely to receive mTOR-directed therapy. These data are in agreement with the known cardiotoxicity associated with both sunitinib and pazopanib [23, 25], such as cardiac dysfunction (sunitinib, $11 \%$ frequency; pazopanib, 13\%) and myocardial infarction/ischemia (sunitinib, 4\% frequency; pazopanib, 2\%) [11]. Similarly, a preference for TK/VEGF inhibitors in those with diabetes can be explained by the fact that hyperglycemia is a well-known AE associated with mTOR inhibitors (observed in 26\% of patients treated with temsirolimus [30] and 50\% treated with everolimus [31]) .

Duration of treatment also varies by agent and may influence treatment choice. Median duration of TK/ VEGF-directed treatment was much longer than that of mTOR-directed treatment (6.3 and 3.9 months); similarly, oral treatment duration was nearly twice that of IV treatment (6.6 and 3.4 months). The median durations of sunitinib and pazopanib treatment were similar to each other ( 6.5 and 7.0 months, respectively), but were longer than those of sorafenib (4.7 months), everolimus (4.0 months), and temsirolimus (3.9 months). Reported results of real-world studies are mixed. For example, the observed sunitinib and sorafenib treatment durations were similar to those reported by Feinberg et al. (5.9 and 5.5 months, respectively) [32] and only slightly longer than those reported by Miller et al. (5.6 and 5.3 months, respectively), who also reported durations of 5.3 months for pazopanib and 4.5 months for everolimus [14]. However, these durations are slightly longer than those reported by Hess et al. (3.2 and 4.0 months, respectively; 2.6 months for temsirolimus) [33] and Vogelzang et al. (sunitinib, 4.1 months; pazopanib 4.8 months) [15]. However, it should be noted that direct cross-study comparisons are not possible based on different analysis methods and populations. Treatment durations reported in the randomized clinical trial setting are also sometimes mixed and are not dissimilar to the results from this study. For instance, Phase III data have shown $1 \mathrm{~L}$ median treatment durations of 7.6 and 8.0 months, respectively, for TK inhibitors sunitinib and pazopanib [11] and 3.9 months for the mTOR inhibitor temsirolimus [30]. Collectively, these data suggest that there are potential differences in patient selection, outcomes measurement and patient preference between real-world data studies and randomized clinical trials that could have implications for future clinical trial design. These differences may reflect the difficulty in (1) maintaining adequate dosing with these relatively toxic agents and (2) reproducing clinical trial results in the real-world setting for $\mathrm{mRCC}$.

Potential differences in toxicities between the $1 \mathrm{~L}$ treatments in this study vs those previously seen were also evaluated, and it was noted that the most common AEs associated with each drug class were generally consistent with previously reported results [34-37] and with the product labels [19-25]. Notably, however, substantial latency of onset was observed for several potentially treatment-related toxicities in patients treated with both TK/VEGF- and mTOR-inhibitor classes, which was much different in clinical practice (i.e., onset of fatigue, hypertension and hepatic dysfunction generally occurs quickly). AE latency in the database may be due to capture of only the toxicities that generate a medical claim and may suggest that the toxicities that are observed early on may not receive medical care in clinical practice. There were also AEs potentially associated with checkpoint inhibitors. The latency of these AEs was similar to that observed with checkpoint inhibitors $[38,39]$. These results suggest that attributing toxicities to TK/ VEGF-directed therapies vs checkpoint inhibitors, when used in combination, may be challenging due to overlapping toxicities.

In contrast to the $1 \mathrm{~L}$ treatment data, $2 \mathrm{~L}$ treatment data were less defined. In this study, nearly half of all patients did not have evidence of receiving $2 \mathrm{~L}$ treatment (47\% [ $n=940]$ ); however, there is no reliable way to determine the reasons for this from a claims database. Patients who did not receive $2 \mathrm{~L}$ therapy in this study may either still be receiving $1 \mathrm{~L}$ targeted therapy (and were not captured in the study due to the follow-up period ending) or have attained sustained remission, died before 
receiving $2 \mathrm{~L}$ therapy, refused $2 \mathrm{~L}$ treatment or did not receive $2 \mathrm{~L}$ therapy for unknown reasons. Consistent with other studies, most patients treated with a $1 \mathrm{~L}$ oral TK inhibitor who received $2 \mathrm{~L}$ therapy were switched to $2 \mathrm{~L}$ mTOR-directed treatment, primarily everolimus [26]; $2 \mathrm{~L}$ treatment choice warrants further investigation.

This study had several strengths and limitations. Strengths include the large number of $1 \mathrm{~L}$-treated patients with $\mathrm{mRCC}$ over time, including those treated with TK/VEGF- or mTOR-directed therapy. The use of the MarketScan databases also provided strength to this study due to the inclusion of the full continuum of care in all inpatient and outpatient settings, as well as retail and specialty pharmacies, and the longitudinal tracking of patient information. However, the MarketScan databases also have limitations, as they are inherently restricted to insured patients and provide limited social background and demographic data. Secondary metastasis codes were not required for identification of patients with $\mathrm{mRCC}$ since the $1 \mathrm{~L}$ treatments are approved in the metastatic setting only and to avoid exclusion of eligible patients due to potential underreporting of secondary metastasis codes. However, the study could have included patients who received the treatments off-label in the adjuvant/neoadjuvant setting. Further, administrative claims-based data are prone to coding and data entry errors. Potential underreporting of secondary metastasis and baseline comorbidities may have affected the point estimates in the multivariate models, and the distribution of these variables may not be representative of the RCC population in clinical practice. Moreover, only AEs of sufficient severity to prompt medical attention and generate a claim could be identified, which may have led to underreported IRs. It was also not possible to discern from the claims data whether an $\mathrm{AE}$ was reported due to a drug reaction, RCC progression or other cause, nor was it possible to know the severity/grade of the AE. Further, it is unknown from the claims data whether $2 \mathrm{~L}$ treatment was received due to toxicity or disease progression. In this study, the treatment duration end date was calculated by adding the days' supply of oral treatment and cycle length for IV treatment. Since most patients receive their oral drug supply 1 to 3 months in advance, the treatment duration for oral medications may have been overestimated. Additionally, the proportion of patients who switched treatment may have been underreported due to the limited follow-up in this study (median of $\approx 16$ months after the index date). However, this median follow-up may be of limited concern considering the low survival rates in this patient population [40, 41]. Lastly, recent approvals (e.g., cabozantinib and nivolumab \pm ipilimumab) and treatment recommendations were not captured given that these agents were not approved during the period covered by the analysis [42-44].

\section{Conclusions}

In this retrospective, claims-based study of patients with mRCC in the Truven Health MarketScan databases, 10-year prescribing trends showed the transition from cytokine-based treatment to targeted agents and a similar shift from IV to oral agents. Observed $1 \mathrm{~L}$ treatment patterns generally suggested good adherence to NCCN guideline recommendations, although treatment durations across the literature appear variable. In all patients and those treated with TK/VEGF- and mTOR-directed $1 \mathrm{~L}$ treatment, the three most common AEs were hypertension, nausea/vomiting and renal insufficiency. The $2 \mathrm{~L}$ treatments included a wide variety of agents for mRCC. With new agents and combinations (e.g., checkpoint inhibitor therapy) emerging following this study period (through 2016), these data will be useful in providing medical benchmarks for contemporary mRCC therapy.

\section{Additional file}

Additional file 1: Table S1. Listing of AEs included for analysis, with ICD-9/ICD-10-CM codes. Table S2. Baseline characteristics by TK inhibitor type. Table S3. Baseline characteristics by VEGF inhibitor type. Table S4. Baseline characteristics by mTOR inhibitor type. (DOCX $71 \mathrm{~kb}$ )

\section{Abbreviations \\ $1 \mathrm{~L}$ : First-line; $2 \mathrm{~L}$ : Second-line; AE: Adverse event; CHF: Congestive heart failure; DCCl: Deyo-Charlson Comorbidity Index; IFN: Interferon; IL: Interleukin; IR: Incidence rate; IV: Intravenous; mRCC: Metastatic renal cell carcinoma; mTOR: Mechanistic target of rapamycin kinase; NCCN: National \\ Comprehensive Cancer Network; ORR: Objective response rate; OS: Overall survival; PFS: Progression-free survival; PY: Patient-years; Q: Quartile; \\ RCC: Renal cell carcinoma; TK: Tyrosine kinase; TT2T: Time to $2 \mathrm{~L}$ treatment; VEGF: Vascular endothelial growth factor}

\section{Acknowledgements}

Medical writing assistance for this manuscript was provided by Ashley J. Pratt, PhD, of Health Interactions, Inc. (San Francisco, CA), and was funded by F. Hoffmann-La Roche, Ltd.

\section{Funding}

This study was sponsored by F. Hoffmann-La Roche, Ltd. The sponsor was involved in the design of the study, the collection, analysis, and interpretation of data as well as final approval of the manuscript. Medical writing assistance was provided by a professional medical writer funded by the sponsor.

\section{Availability of data and materials}

The data that support the findings of this study are available from Truven Health Analytics ${ }^{\circledR}$ (part of the IBM Watson Health business), but restrictions apply to the availability of these data, which were used under license for the current study.

\section{Authors' contributions}

SP, SKM, S-WL, SO and DG contributed to study design. AS contributed to data analysis. All authors contributed to the interpretation of results and preparation of the manuscript, gave approval to submit the manuscript and agree to be accountable for the work.

\section{Authors' information}

Not applicable

Ethics approval and consent to participate

This study used Truven MarketScan retrospective administrative claims data. Data were de-identified and comply with the Health Insurance Portability 
and Accountability Act and the 1964 Helsinki Declaration and its later amendments or comparable ethical standards. Thus, Institutional Review Board approval was not required, and formal informed consent was not obtained.

\section{Consent for publication}

Not applicable.

\section{Competing interests}

SP reports honoraria and a consulting/advisory role with Novartis, Astellas, Aveo, Bristol-Myers Squibb, Eisai, Exelixis, Ipsen, Myriad Pharmaceuticals, Pfizer and Roche/Genentech and honoraria and research funding from Medivation. AS is employed by Genesis Research and reports a consulting/advisory role with Roche/Genentech. SKM, SW and SO are employees of Genentech, Inc. and own Roche stock. DG reports consulting/advisory roles with Astellas, AstraZeneca, Bayer, Bristol-Myers Squibb, Clovis, Exelixis, Genentech/Roche, Innocrin, Janssen, Myovant, Pfizer and Sanofi and received research funding from Astellas, Bayer, Innocrin, Janssen, Novartis and Pfizer. HW is a former employee of Roche/Genentech. RV was a paid intern at Roche/Genentech at the time of the study. JG declares that he has no competing interests.

\section{Publisher's Note}

Springer Nature remains neutral with regard to jurisdictional claims in published maps and institutional affiliations.

\begin{abstract}
Author details
${ }^{1}$ Department of Medical Oncology and Experimental Therapeutics, City of Hope National Medical Center, 1500 East Duarte Road, Duarte, CA 91010, USA. ${ }^{2}$ Department of Hematology/Oncology, City of Hope National Medical Center, 1500 East Duarte Road, Duarte, CA 91010, USA. ${ }^{3}$ Real World Data Science (Oncology), Genentech, Inc, 1 DNA Way, MS 352B, South San Francisco, CA 94080, USA. ${ }^{4}$ Genesis Research, 5 Marine View Plaza, Hoboken, NJ 07030, USA. ${ }^{5}$ US Medical Affairs, Genentech, Inc, 1 DNA Way, MS 352B, South San Francisco, CA 94080, USA. ${ }^{6}$ School of Pharmacy, West Virginia University, P.O. Box 9500, Morgantown, W 26506, USA. ${ }^{7}$ Oncology and Hematology Care Clinic, Providence Cancer Center, 4805 NE Glisan Street, Suite 6N40, Portland, OR 97213, USA. ${ }^{8}$ Department of Medicine, Medical Oncology, Duke University School of Medicine, Box 103861, Durham, NC 27710, USA.
\end{abstract}

Received: 23 January 2018 Accepted: 14 May 2019 Published online: 07 June 2019

\section{References}

1. National Cancer Institute. SEER Cancer Stat Facts: Kidney and Renal Pelvis Cancer. https://seer.cancer.gov/statfacts/html/kidrp.html. Accessed 3 Feb 2019.

2. Ljungberg B, Campbell SC, Choi HY, et al. The epidemiology of renal cell carcinoma. Eur Urol. 2011;60(4):615-21.

3. Gupta K, Miller JD, Li JZ, Russell MW, Charbonneau C. Epidemiologic and socioeconomic burden of metastatic renal cell carcinoma (mRCC): a literature review. Cancer Treat Rev. 2008;34(3):193-205.

4. Pal SK, Ghate SR, Li N, et al. Real-world survival outcomes and prognostic factors among patients receiving first targeted therapy for advanced renal cell carcinoma: a SEER-Medicare database analysis. Clin Genitourin Cancer. 2017;15(4):e573-82.

5. American Cancer Society. Survival rates for kidney cancer by stage. https:// www.cancer.org/cancer/kidney-cancer/detection-diagnosis-staging/survivalrates.html. Accessed 3 Feb 2019.

6. Heng DY, Xie W, Bjarnason GA, et al. Progression-free survival as a predictor of overall survival in metastatic renal cell carcinoma treated with contemporary targeted therapy. Cancer. 2011;117(12):2637-42.

7. Sun M, Larcher A, Karakiewicz PI. Optimal first-line and second-line treatments for metastatic renal cell carcinoma: current evidence. Int J Nephrol Renovasc Dis. 2014;7:401-7

8. NCCN. Clinical practice guidelines in oncology. Kidney Cancer, Version 2. 2019. https://www.nccn.org/professionals/physician_gls/PDF/kidney.pdf. Accessed 3 Jan 2019.

9. Motzer RJ, Hutson TE, Tomczak $P$, et al. Sunitinib versus interferon alfa in metastatic renal-cell carcinoma. N Engl J Med. 2007;356(2):115-24.
10. Sternberg CN, Davis ID, Mardiak J, et al. Pazopanib in locally advanced or metastatic renal cell carcinoma: results of a randomized phase III trial. J Clin Oncol. 2010;28:1061-8.

11. Motzer RJ, Hutson TE, Cella D, et al. Pazopanib versus sunitinib in metastatic renal-cell carcinoma. N Engl J Med. 2013;369(8):722-31.

12. MacLean E, Mardekian J, Cisar LA, Hoang CJ, Harnett J. Real-world treatment patterns and costs for patients with renal cell carcinoma initiating treatment with sunitinib and pazopanib. J Manag Care Spec Pharm. 2016;22(8):979-90.

13. Clark Jl, Wong MK, Kaufman $\mathrm{HL}$, et al. Impact of sequencing targeted therapies with high-dose interleukin-2 immunotherapy: an analysis of outcome and survival of patients with metastatic renal cell carcinoma from an on-going observational IL-2 clinical trial: PROCLAIMSM. Clin Genitourin Cancer. 2017;15(1):31-41.e4.

14. Miller LA, Stemkowski S, Saverno K, et al. Patterns of care in patients with metastatic renal cell carcinoma among a U.S. payer population with commercial or Medicare advantage membership. J Manag Care Spec Pharm. 2016;22(3):219-26.

15. Vogelzang NJ, Pal SK, Ghate SR, et al. Real-world economic outcomes during time on treatment among patients who initiated sunitinib or pazopanib as first targeted therapy for advanced renal cell carcinoma: a retrospective analysis of Medicare claims data. J Manag Care Spec Pharm. 2018:24:525-33.

16. Rao A, Wiggins C, Lauer RC. Survival outcomes for advanced kidney cancer patients in the era of targeted therapies. Ann Transl Med. 2018;6:165.

17. Klabunde CN, Potosky AL, Legler JM, Warren JL. Development of a comorbidity index using physician claims data. J Clin Epidemiol. 2000;53(12):1258-67.

18. Deyo RA, Cherkin DC, Ciol MA. Adapting a clinical comorbidity index for use with ICD-9-CM administrative databases. J Clin Epidemiol. 1992;45(6):613-9.

19. TORISEL. (temsirolimus) [package insert]. Philadelphia, PA: Wyeth Pharmaceuticals Inc.; 2017.

20. AFINITOR (everolimus) [package insert]. East Hanover. NJ: Novartis Pharmaceuticals Corporation; 2017.

21. Avastin (bevacizumab) [summary of product characteristics]. GrenzachWyhlen. Germany: Roche Registration GmbH; 2016.

22. INLYTA (axitinib) [package insert]. New York, NY: Pfizer Laboratories; 2014.

23. VOTRIENT (pazopanib) [package insert]. East Hanover. NJ: Novartis Pharmaceuticals Corporation; 2017.

24. NEXAVAR (sorafenib) [package insert]. Wayne. NJ: Bayer HealthCare Pharmaceuticals Inc.; 2015.

25. SUTENT (sunitinib) [package insert]. New York, NY: Pfizer Laboratories; 2017.

26. Jonasch $E$, Signorovitch JE, Lin PL, et al. Treatment patterns in metastatic renal cell carcinoma: a retrospective review of medical records from US community oncology practices. Curr Med Res Opin. 2014;30(10):2041-50.

27. Harshman LC, Srinivas S. The bevacizumab experience in advanced renal cell carcinoma. Onco Targets Ther. 2010;3:179-89.

28. Yang JC, Haworth L, Sherry RM, et al. A randomized trial of bevacizumab, an anti-vascular endothelial growth factor antibody, for metastatic renal cancer. N Engl J Med. 2003;349(5):427-34.

29. Bukowski RM, Kabbinavar FF, Figlin RA, et al. Randomized phase II study of erlotinib combined with bevacizumab compared with bevacizumab alone in metastatic renal cell cancer. J Clin Oncol. 2007;25(29):4536-41.

30. Hudes G, Carducci M, Tomczak P, et al. Temsirolimus, interferon alfa, or both for advanced renal-cell carcinoma. N Engl J Med. 2007;356(22):2271-81.

31. Motzer RJ, Escudier B, Oudard S, et al. Efficacy of everolimus in advanced renal cell carcinoma: a double-blind, randomised, placebo-controlled phase III trial. Lancet. 2008;372(9637):449-56.

32. Feinberg BA, Jolly P, Wang ST, et al. Safety and treatment patterns of angiogenesis inhibitors in patients with metastatic renal cell carcinoma: evidence from US community oncology clinics. Med Oncol. 2012;29:786-94.

33. Hess G, Borker R, Fonseca E. Treatment patterns: targeted therapies indicated for first-line management of metastatic renal cell carcinoma in a real-world setting. Clin Genitourin Cancer. 2013;11:161-7.

34. Schmidinger M. Understanding and managing toxicities of vascular endothelial growth factor (VEGF) inhibitors. EJC Suppl. 2013;11(2):172-91.

35. Dy GK, Adjei AA. Understanding, recognizing, and managing toxicities of targeted anticancer therapies. CA Cancer J Clin. 2013;63(4):249-79.

36. Ravaud A. Treatment-associated adverse event management in the advanced renal cell carcinoma patient treated with targeted therapies. Oncologist. 2011;16(suppl 2):32-44. 
37. Pal SK, Figlin RA. Treatment options in metastatic renal cell carcinoma: focus on mTOR inhibitors. Clin Med Insights Oncol. 2010;4:43-53.

38. Nishino M, Tirumani SH, Ramaiya NH, Hodi FS. Cancer immunotherapy and immune-related response assessment: the role of radiologists in the new arena of cancer treatment. Eur J Radiol. 2015;84(7):1259-68.

39. Weber JS, Kudchadkar RR, Yu B, et al. Safety, efficacy, and biomarkers of nivolumab with vaccine in ipilimumab-refractory or -naive melanoma. J Clin Oncol. 2013;31(34):4311-8.

40. Harrison MR, Hirsch BR, George DJ, et al. Real-world outcomes in metastatic renal cell carcinoma: insights from a joint community-academic registry. J Oncol Pract. 2014;10(2):e63-72.

41. Beisland C, Johannesen TB, Klepp O, et al. Overall survival in renal cell carcinoma after introduction of targeted therapies: a Norwegian population-based study. Onco Targets Ther. 2017;10:371-85.

42. OPDIVO (nivolumab) [package insert]. Princeton. New Jersey: Bristol-Myers Squibb Company; 2018.

43. YERVOY. (ipilimumab) [package insert]. Princeton, NJ: Bristol-Myers Squibb Company; 2018.

44. COMETRIQ. (cabozantinib) [package insert]. Alameda, CA: Exelixis, Inc:; 2018.

Ready to submit your research? Choose BMC and benefit from:

- fast, convenient online submission

- thorough peer review by experienced researchers in your field

- rapid publication on acceptance

- support for research data, including large and complex data types

- gold Open Access which fosters wider collaboration and increased citations

- maximum visibility for your research: over $100 \mathrm{M}$ website views per year

At $\mathrm{BMC}$, research is always in progress.

Learn more biomedcentral.com/submissions 